\title{
OA04-02. Strong HIV-specific CD4 and CD8 T-lymphocyte proliferation in HIV-I DNA prime/modified vaccinia virus Ankara (MVA) heterologous boost vaccinees
}

\author{
C Nilsson*1, S Aboud ${ }^{2}$, K Karlén ${ }^{1}$, M Marovich³ ${ }^{3}$ B Wahren1', E Sandström4 \\ $\mathrm{H}_{\text {Gaines }}{ }^{1}$, G Biberfeld ${ }^{1}$ and K Godoy-Ramirez ${ }^{1}$
}

Address: ${ }^{1}$ Immunology and Vaccinology, Swedish Institute for Infectious Disease Control, Karolinska Institute, Solna, Sweden, ${ }^{2}$ Muhimbili University of Health and Allied Sciences, Dar es Salaam, Tanzania, ${ }^{3}$ Walther Reed Army Institute for Research, Rockville, MD, USA and ${ }^{4}$ Venhälsan and Karolinska Institutet, Stockholm, Sweden

* Corresponding author

from AIDS Vaccine 2009

Paris, France. 19-22 October 2009

Published: 22 October 2009

Retrovirology 2009, 6(Suppl 3):O26 doi:10.1 186/1742-4690-6-S3-O26

This abstract is available from: http://www.retrovirology.com/content/6/S3/O26

(c) 2009 Nilsson et al; licensee BioMed Central Ltd.

\section{Background}

We determined HIV-1-vaccine-induced lymphoproliferative responses in vaccinees immunized with a multigene, multiclade HIV-1 plasmid DNA vaccine boosted with heterologous HIV-1 recombinant MVA in a phase I HIV safety and immunogenicity study (HIVIS01/02).

\section{Methods}

Healthy volunteers were immunized intradermally or intramuscularly (with or without adjuvant GM-CSF protein) with DNA expressing HIV-1 gag, env, rev and rt at months 0,1 and 3 using a Biojector and were boosted at nine months with an MVA expressing heterologous inserts of HIV-1 gag, env and pol genes. Lymphoproliferative responses to AT-2 inactivated HIV-1 antigen were tested by a $3 \mathrm{H}$-thymidine uptake assay and a flow-cytometric assay of specific cell-mediated immune-response in activated whole blood (FASCIA-WB) two weeks after HIV-1 MVA boost $(\mathrm{n}=38)$. A FASCIA using peripheral blood mononuclear cells (FASCIA-PBMC) was also employed during the later part of the study $(\mathrm{n}=14)$.

\section{Results}

Thirty-five of 38 (92\%) vaccinees were reactive by the $3 \mathrm{H}-$ thymidine-uptake assay (SI > 8). Thirty-two of 38 (84\%) vaccinees were reactive by the $\mathrm{CD} 3+\mathrm{CD} 4+\mathrm{T}$-cell FASCIAWB (\% stimulation $>1.2)$, seven $(18 \%)$ also exhibited
CD8+ (CD3+ CD4-) T-cell responses. Of the 14 vaccinees analyzed using all three assays, ten (71\%) and eleven $(79 \%)$ demonstrated CD4+ T-cell responses in FASCIA$\mathrm{WB}$ and FASCIA-PBMC, respectively. CD8+ T-cell reactivity was observed in 3 of $14(21 \%)$ and 7 of $14(50 \%)$ using the FASCIA-WB and FASCIA-PBMC, respectively. There was strong correlation between the proliferative responses measured by the $3 \mathrm{H}$-thymidine uptake assay and the CD4+ T-cell FASCIA-WB $(r=0.68 ; \mathrm{p}<0.01)$.

\section{Conclusion}

HIV-1 specific T-lymphocyte proliferative responses were detected in a high proportion (37/38) of volunteers following HIV-1 DNA/MVA immunization. The FASCIA revealed both $\mathrm{CD} 4+$ and $\mathrm{CD} 8+\mathrm{T}$-cell proliferation in response to HIV-1 antigen stimulation. A standardized FASCIA-PBMC, which allows simultaneous phenotyping may be an option to the conventional $3 \mathrm{H}$-thymidine uptake assay for assessment of vaccine-induced T-cell proliferation, especially in isotope-restricted settings. 